\title{
ZAGADNIENIE PERSONALIZMU W PROTREPTYKU KLEMENSA ALEKSANDRYJSKIEGO
}

Myśliciele starożytni wypracowali trzy rodzaje paradygmatu opisującego problematykę makro i mikrokosmosu: metafizykę arystotelesowską (ontologię), naukę o bycie jako bycie; metafizykę henologiczną, analizującą rzeczywistość w kategoriach ,jedności” i „wielości” propagowana przez eleatów, Platona, Akademię i Plotyna, oraz metafizykę osoby, która jest syntezą dwóch paradygmatów: arystotelesowskiego i henologicznego. Giovanni Reale, znawca filozofii antycznej, analizując twórczość poetycką, filozoficzną i teologiczną Karola Wojtyły (św. Jana Pawła II) zauważa, ze starożytni myśliciele chrześcijańscy przyswoili sobie te dwa paradygmaty: „Ojcowie Kościoła starali się wypracować wersję pośrednią, zachowując jednak wyższość Jednego nad Bytem; scholastycy nadali niemal absolutny prymat metafizyce bytu. Jednakże w obszarze myśli chrześcijańskiej narodził się trzeci paradygmat - metafizyka osoby". Badacze problematyki antropologicznej analizując naukę o człowieku podkreślali różne aspekty istoty ludzkiej na płaszczyźnie filozoficznej i teologicznej. Antropologią filozoficzną interesowali się między innymi: R. Ingarden ${ }^{2}$, E.L. Mascall ${ }^{3}$. M. Gogacz', M.A. Krapiec ${ }^{5}$, J. Geveart ${ }^{6}$, B. Mon$\operatorname{din}^{7}$, H.A. Wolfson ${ }^{8}$, J. Tischner ${ }^{9}$, K. Wojtyła/Jan Paweł II ${ }^{10}$, J. Galarowicz ${ }^{11}$,

* Ks. dr Aleksy Kowalski - wykładowca patrologii w Wyższym Seminarium Duchownym Archidiecezji Częstochowskiej; e-mail: aleksy.kowalski@gmail.com.

${ }^{1}$ G. Reale, Karol Wojtyła Pielgrzym absolutu, thum. M. Gajda, Warszawa 2008, 61.

${ }^{2}$ Por. R. Ingarden, Ksiażeczka o człowieku, Kraków 2009.

${ }^{3}$ Por. E.L. Mascall, Chrześcijańska koncepcja człowieka i wszechświata, tłum. H. Bednarek S. Zalewski, Warszawa 1986, 9-94.

${ }^{4}$ Por. M. Gogacz, Wokót problemu osoby, Warszawa 1974.

${ }^{5}$ Por. M.A. Krapiec, Ja człowiek. Zarys antropologii filozoficznej, Lublin 1986.

${ }^{6}$ Por. J. Geveart, Il problema dell'uomo. Introduzione all'antropologia filosofica, Torino 1992.

${ }^{7}$ Por. B. Mondin, L'uomo: chi è?, Milano 1993.

${ }^{8}$ Por. H.A. Wolfson, La filosofia dei Padri della Chiesa, t. 1: Spirito, Trinita, Incarnazione, trad.

L.C. Ginelli, Brescia 1978.

${ }^{9}$ Por. J. Tischner, Spór o czlowieka, Kraków 2011.

${ }^{10}$ Por. K. Wojtyła, Osoba i czyn oraz inne studia antropologiczne, Lublin 2000; Reale, Karol Wojtyła, s. 44-62.

${ }^{11}$ Por. J. Galarowicz, Być ziarnem pszenicznym. Mała ksiażeczka o człowieku, Kęty 2006. 
S. Kowalczyk ${ }^{12}$, C. Stead ${ }^{13}$, G. Barth ${ }^{14}$ i M. Szymonik ${ }^{15}$. Zagadnienia antropologii teologicznej podejmują naukowcy, dla których punktem wyjścia jest przede wszystkim Biblia i Tradycja. Do tej grupy miłośników teologii należą między innymi: J.H. Newman ${ }^{16}$, W. Granat ${ }^{17}$, C.S. Bartnik ${ }^{18}$, S. Bułgakow ${ }^{19}$, M. Bierdiajew ${ }^{20}$, P. Tillich ${ }^{21}$, J. Daniélou ${ }^{22}$, K. Rahner ${ }^{23}$, H. Urs von Balthasar ${ }^{24}$, V. Grossi ${ }^{25}$, I. Sanna ${ }^{26}$, G. Colzani ${ }^{27}$, J.L. Ruiz del la Peña ${ }^{28}$, B. Mondin ${ }^{29}$, P. Nel$\operatorname{las}^{30}$, C.A. Hall ${ }^{31}$, J. Ratzinger/Benedykt XVI ${ }^{32}$, J. Pałucki ${ }^{33}$, K. Guzowski ${ }^{34}$, A. Baron ${ }^{35}$ oraz inni.

1. Problematyka czlowieka w filozofii starożytnej. W myśli helleńskiej pojęcie „osoby” ( $\tau$ ò $\pi \rho o ́ \sigma \omega \pi \mathrm{ov})^{36}$ nie otrzymuje statusu wartości absolutnej w relacji do innych bytów. Arystoteles podkreśla znaczenie ludzkiego

${ }^{12}$ Por. S. Kowalczyk, Nurty personalizmu. Od Augustyna do Wojtyly, Lublin 2010.

${ }^{13}$ Por. C. Stead, Philosophy in Christian Antiquity, New York 1994.

${ }^{14}$ Por. G. Barth, Hermeneutyka osoby, Lublin 2013.

${ }^{15}$ Por. M. Szymonik, Filozoficzne podstawy kategorii godności człowieka w ujęciu personalizmu szkoty lubelskiej, Lublin 2015.

${ }^{16}$ Por. J.H. Newman, The Arians of the Fourth Century, Notre Dame 2001.

${ }^{17}$ Por. W. Granat, Personalizm chrześcijański. Teologia osoby ludzkiej, Poznań 1985.

${ }^{18}$ Por. C.S. Bartnik, Personalizm, Lublin 2000.

${ }^{19}$ Por. S. Bułgakow, Światto wieczności, thum. J. Chmielewski, Kęty 2010.

${ }^{20}$ Por. M. Bierdiajew, O przeznaczeniu człowieka. Zarys etyki paradoksalnej, tłum. H. Paprocki, Kęty 2006.

${ }^{21}$ Por. P. Tillich, Pytanie o nieuwarunkowane, thum. J. Zychowicz, Kraków1994.

${ }^{22}$ Por. J. Daniélou, Messaggio evangelico e cultura ellenistica, thum. C. Prandi, Bologna 1975, 453-497.

${ }^{23}$ Por. K. Rahner, Stuchacz Stowa, thum. R. Samek, Kęty 2008.

${ }^{24}$ Por. H. Urs von Balthasar, Teodramatyka. Osoby dramatu. Człowiek w Bogu, t. 2/1, thum. W. Szymona, Kraków 2006.

${ }^{25}$ Por. V. Grossi, Lineamenti di antropologia patristica, Città di Castello 1983, 5-78.

${ }^{26}$ Por. I. Sanna, Immagine di Dio e libertà umana. Per un'antropologia a misura d'uomo, Roma 1990.

${ }^{27}$ Por. G. Colzani, Antropologia cristiana. Il dono e la responsabilità, Casale Monferrato 1991.

${ }^{28}$ Por. J.L. Ruiz de la Peña, Immagine di Dio. Antropologia teologica fondamentale, trad.

R. Del Guerra, Città di Castello 1992.

${ }^{29}$ Por. B. Mondin, L'uomo secondo il disegno di Dio. Trattato di antropologia teologica, Bologna 1992.

${ }^{30}$ Por. P. Nellas, Voi siete Dei. Antropologia dei Padri della chiesa, thum. A. Fyrigos, Roma 1993.

${ }^{31}$ Por. C.A. Hall, Learning Theology with the Church Fathers, Downers Grave 1989.

${ }^{32}$ Por. J. Ratzinger, Wprowadzenie w chrześcijaństwo, tłum. Z. Włodkowa, Kraków 1994; Benedykt XVI, Katechezy o Ojcach Kościoła, Kraków 2008.

${ }^{33}$ Por. J. Pałucki, Pojęcie „, osoby” w Kościele pierwszych wieków, „Personalizm” 6 (2004) 79-92.

${ }^{34}$ Por. K. Guzowski, Co to jest personalizm?, w: Wspótczesny fenomen osoby, red. K. Guzowski - G. Barth, Lublin 2011, 13-26.

${ }^{35}$ Por. A. Baron, Świętość a ideaty czlowieka, Kraków 2013.

${ }^{36}$ Por. Lampe, Oxford 19899, 1186-1189. 
rozumu (ó vov̂s) $)^{37}$, który według Stagiryty stanowi najdoskonalszy element w człowieku. Życie zgodne z rozumem to przejaw boskiej egzystencji, ponieważ Bóg jest Rozumem Najwyższym. Człowiek w hierarchii kosmosu zajmuje niższą pozycję niż inne byty. Arystoteles tak pisze w Etyce nikomachejskiej:

„Argument zaś, że człowiek stoi spośród wszystkich stworzeń żyjących najwyżej, jest bez znaczenia. Istnieją, bowiem twory, których natura jest dużo bardziej boska niż natura człowieka, jak np. najbardziej widoczne spomiędzy nich, te [ciała niebieskie], z których składa się wszechświat”38.

Metafizyka kosmocentryczna Stagiryty podkreśla hierarchiczność ontologiczna, w której natura ciał niebieskich tworzących strukturę wszechświata charakteryzuje się większą boskością niż natura ludzka. Element boski człowieka nie jest tak wyraźny jak w innych komponentach, z których jest zbudowane uniwersum.

Metafizyka henologiczna Plotyna prezentuje proces emanacji trzech hipostaz. „Jedno” będące pierwszą hipostazą emanuje drugą - „Umysł-Myśl”, ta zaś generuje trzecią hipostazę - „Duszę świata”. Autor Ennead nawiązując

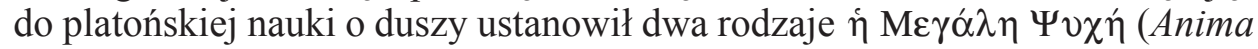
mundi) - wyższą i niższą. Pierwsza (wyższa) znajduje się bliżej „Umysłu”, nie mając bezpośredniego kontaktu ze światem materialnym; druga - niższa, będąc duszą świata cielesnego, jest nazwana „naturą" ( $\varphi v ́ \sigma \varsigma)^{39}$. Idee przebywa-

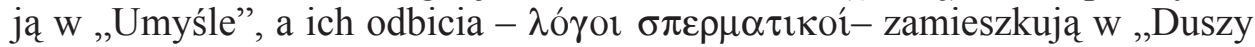
świata". Plotyn nawiązując do doktryny stoickiej o logosie umieścił w wyż-

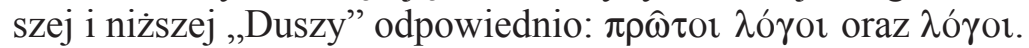

Człowiek w antropologii plotyńskiej istnieje najpierw w postaci duchowej, w świecie idei, aby później na ziemi otrzymać ludzkie ciało. Zrównania człowieka z duszą po raz pierwszy dokonał już Sokrates. Platon rozwinął rozumienie ontologiczne tego stwierdzenia, Plotyn zaś konsekwentnie zastosował ów paradygmat do nauki o człowieku. Twórca neoplatonizmu stwierdza, że w istocie ludzkiej egzystują jak gdyby ,trzej ludzie”, a nie tylko człowiek wewnętrzny i człowiek zewnętrzny. Reale konstatuje, iż ten potrójny podział ,jest wyraźny także przy zastosowaniu terminu «dusza», w tym sensie, że «trzech ludzi» można uważać za trzy dusze, albo raczej za «trzy władze» duszy. «Pierwszym człowiekiem» jest po prostu dusza rozpatrywana w jej styczności z Umysłem (styczności tej strukturalnie dusza nigdy nie traci); «drugim człowiekiem» jest dusza, jako myśl dyskursywna, która zajmuje miejsce pośrednie między tym, co inteligibilne a tym, co zmysłowe; «trzecim człowiekiem» zaś jest dusza, która ożywia ciało ziemskie"40. Metafizyka henologiczna Ploty-

${ }^{37}$ Por. tamże, s. 923-927.

${ }^{38}$ Aristoteles, Ethica nicomachea VI 1141b, ed. O. Apelt, Leipzig 1912, thum. D. Gromska: Arystoteles, Etyka Nikomachejska, Warszawa 1982, 61.

${ }^{39}$ Por. F. Copleston, Historia filozofii. t. 1: Grecja i Rzym, thum. H. Bednarek, Warszawa 1998, 421.

${ }^{40} \mathrm{G}$. Reale, Myśl starożytna, thum. E.I. Zieliński, Lublin $2010^{2}, 566$. 
na demonstruje hierarchiczną ontologię emanacji, w której człowiek-dusza egzystuje jako rzeczywistość powołana do istnienia in via emanationis, na której „Jeden”, „Umysł” i „Dusza świata” przewyższają istotę ludzką swoją boskością i doskonałością. A zatem człowiek, w kosmocentrycznej doktrynie perypatetyków oraz w panteistycznej nauce neoplatoników, posiada tylko wartość relatywną. Stanowi on punkt odniesienia i nie znajduje się w centrum ówczesnego wszechświata.

2. Personalistyczna eikonantropologia Klemensa z Aleksandrii. Tytus Flawiusz Klemens z Aleksandrii, jeden z wybitnych przedstawicieli chrześcijańskiej szkoły aleksandryjskiej, żyjący na przełomie II i III wieku, podejmuje w swoich traktatach wiele zagadnień filozoficzno-teologicznych. Apologeta z Aleksandrii, jak podaje Euzebiusz z Cezarei w swojej Historii Kościelnej,

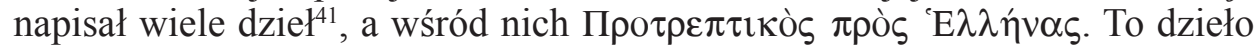
jest znane jako: Upomnienie do Greków (Euzebiusz z Cezarei), Adversus Gentes (św. Hieronim), Cohortatio ad Gentes (Tadeusz Sinko) czy też Zachęta Greków (Jan Sołowianiuk). Benedykt XVI wyjaśniając znaczenie słowa protreptyk stwierdza:

„zgodnie ze znaczeniem tego słowa, stanowi «wezwanie» skierowane do tych, którzy są na początku i poszukują drogi wiary. A jeszcze trafniej - «Protreptyk» odpowiada Osobie: Synowi Bożemu, Jezusowi Chrystusowi, który «wzywa» ludzi by zdecydowanie weszli na drogę prowadzącą do Prawdy"42.

Termin grecki $\pi \rho \circ \tau \rho \varepsilon \pi \tau$ «ó (w sposób zachęcający, przekonywujący) ${ }^{43}$ jest nie tylko tytułem dzieła, lecz także gatunkiem literackim ${ }^{44}$, nakłaniającym czytelnika do uprawiania filozofii. W starożytności tą formą posługiwali się pisarze i filozofowie. Arystoteles w swojej Zachęcie do studiowania filozofii,

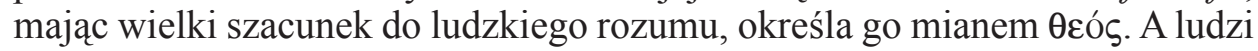
żyjących w harmonii z vov̂s porównuje do mieszkańców wysp, na których króluje szczęście ${ }^{45}$. Podobnie, sześć wieków później, cesarz Marek Aureliusz prawdopodobnie znający poglądy twórcy szkoły perypatetyckiej, stwierdzi, że rozum jest bogiem w człowieku ${ }^{46}$. Cyceron pisze swojego Hortensjusza,

\footnotetext{
${ }^{41}$ Por. Eusebius Caesariensis, HE VI 13, 1-9; Hieronymus, De viris illustribus 38.

${ }^{42}$ Benedictus XVI, Catechesis patristica, OsRom 147 (2007) nr 88, s. 4, thum. pol.: Benedykt XVI, Katechezy o Ojcach Kościoła, s. 25-26.

${ }^{43}$ Por. Lampe, s. 1190; Dizionario illustrato greco-italiano, ed. H.G. Liddell - R. Scott G. Cataudella, Firenze 1993, 1114.

${ }^{44}$ Por. Stownik terminów literackich, red. J. Sławiński, Wrocław 1988, 402: „Protreptyk - w piśmiennictwie starożytnym gatunek dydaktycznej literatury: mowa lub dialog zawierające zachęty do doskonalenia się moralnego i rozwijania zdolności intelektualnych, zwłaszcza zaś wskazówki dotyczące studiowania filozofii”.

${ }^{45}$ Por. K. Leśniak, Arystoteles, Warszawa 1989, 38-39.

${ }^{46}$ Por. Marcus Aurelius, De seipso et ad seipsum 12, 26.
} 
w którym posługując się formą dialogu, zachęca do uprawiania filozofii ${ }^{47}$. Seneka Młodszy, zwany Filozofem, proponuje umiłowanie mądrości w czasie prześladowania myślicieli wyznających poglądy stoickie ${ }^{48}$. W dialogu $D e$ constantia sapientis zaprasza do filozofowania $\mathrm{w}$ duchu stoickim i propagując ideał stoickiego mędrca wskazuje na szczególne zalety człowieka, który miłując mądrość jest sąsiadem i krewnym bogów ${ }^{49}$. Bliskość bóstwa oraz jego interpersonalne relacje $\mathrm{z}$ osobą ludzką kreują w niej podobieństwo do Boga, do którego zmierza. Analogiczną opinię prezentuje Boecjusz z Dacji, filozof, który przekonuje, w swoim traktacie De summo bono sive De vita philosophi, powołując się na autorytet Stagiryty, o szczególnej boskiej roli umysłu ludzkiego w życiu człowieka ${ }^{50}$.

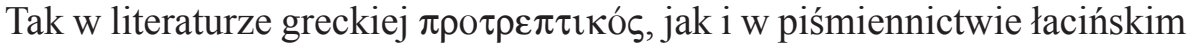
cohortatio, ma długą tradycję. Pisarze chrześcijańscy również posługują się tym rodzajem literackim. Mowa na Areopagu św. Pawła Apostoła, zamiesz-

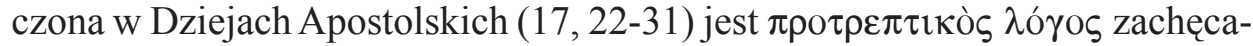
jącą Ateńczyków do przyjęcia wiary w Zmartwychwstałego Chrystusa ${ }^{51}$.

Wśród traktatów zachowanej trylogii Klemensa Aleksandryjskiego znajduje się Zachęta do Greków, której paradygmatem, jak pisze Werner Jaeger, jest

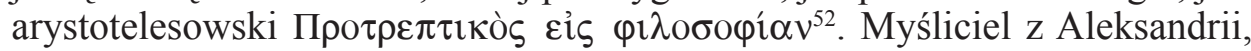
mając jako wzór wcześniejszych apologetów chrześcijańskich (Justyn, Atenagoras) krytykuje religię pogańską wraz z jej zabobonami, okrucieństwem

\footnotetext{
${ }^{47}$ Por. K. Kumaniecki, Historia kultury starożytnej Grecji i Rzymu, Warszawa 1987, 403.

${ }^{48}$ Por. tamże, s. 509.

${ }^{49}$ Por. Lucius Annaeus Seneca, De constantia sapientis 8, 2.

${ }^{50}$ Por. Boethius, De summo bono sive De vita philosophi 298.

${ }^{51}$ Por. C. Moreschini - E. Norelli, Storia della letteratura cristiana antica greca e latina, t. 1:
} Da Paolo all'età costantiniana, Brescia 1995, 97; W. Jaeger, Wczesne chrześcijaństwo i grecka paideia, tłum. K. Bielawski, Bydgoszcz 2002, 30-31; G. Lebreton - G. Zeiller, Storia della Chiesa, t. 1: La Chiesa primitive, Torino 1979, 227-229; J. Sołowianiuk, Wstęp, w: Apologie, PSP 44, Warszawa 1988, 102: „Mowę św. Pawła na Areopagu Ateńskim można by zaliczyć do «lógos protreptikós», bowiem zachowuje schemat tego gatunku. Najpierw Apostoł stwierdza niewystarczalność myśli pogańskiej do poznania najwyższej prawdy, którą jest Bóg, następnie ukazuje piękno nauki Chrystusa i zachęca do jej przyjęcia".

${ }^{52}$ Por. Jaeger, Wczesne chrześcijaństwo, s. 75: „Klemens jest pisarzem innego rodzaju. W swoim Protreptyku posługuje się formą literacką, którą greccy filozofowie stosowali od czasów Sokratesa i Arystotelesa w celu zachęcenia i nakłonienia ludzi do przyjęcia ich sposobu życia. W protreptycznym logos filozofię zalecano jako drogę szczęścia i sposób na poznanie celu ludzkiego życia, co z kolei było konieczne dla osiagnięcia prawdziwego dobra. Ta forma wypowiedzi często zmieniała się zależnie od typu filozofii, jaką przedstawiała, ale nie była tak stereotypowa, jak to sobie czasami uczeni wyobrażali $[. .$.$] a pochwała chrześcijaństwa autorstwa Klemensa odbiega zupełnie od$ takich pogańskich modeli. Jest w znacznej mierze polemiczna, skierowana przeciwko reckiej religii i filozofii, ale mimo to w oczywisty sposób naśladuje filozoficzny typ gatunku literackiego". Zob. T. Sinko, Zarys literatury greckiej, t. 2, Warszawa 1959, 401-402; M. Simonetti, La letteratura cristiana antica greca e latina, Milano 1988, 104-105; tenże, Cristianesimo antico e cultura greca, Città di Castello 1990, 50-51. 
oraz erotyzmem, praktykowanymi w obrzędowości misteriów, aby następnie, czerpiąc argumenty z filozofii i Biblii zachęcać do przyjęcia nauki Logosu - Chrystusa ${ }^{53}$. Zachęta do Greków Klemensa, w odróżnieniu od jego Pedagoga, adresowanego do chrześcijan, jest cohortatio skierowaną do czytelnika pogańskiego ${ }^{54}$. Protreptyk Aleksandryjczyka składa się ze wstępu - exordium (rozdział 1), zakończenia - peroratio (rozdział 12) oraz części centralnej refutatio et argumentatio (rozdziały 2-11); wstęp oraz zakończenie zawieraja odpowiednio elementy protologii i eschatologii. Sophie van der Meeren wyróżnia w strukturze literackiej protreptyka filozoficznego dwa wzajemnie oddziaływujące na siebie elementy: refutatio - pars destruens oraz argumentatio - pars construens ${ }^{55}$.

Protreptyk Klemensa z Aleksandrii zawiera w sobie następujące zagadnienia: rozdział pierwszy wprowadza chrześcijaństwo jako prawdziwą religię, która zastapi greckie zabobony. Ta wymiana jest przedstawiona za pomocą metafory muzycznej. Nowa Pieśń Logosu zastąpi starą. Ton uroczysty wraz z figurami retorycznymi przygotowuje pozytywny nastrój adresata do racjonalnych argumentów, które będą użyte w przyszłości. Rozdział drugi rozpoczyna refutatio helleńskich bogów, religii, proroctw i misteriów wyśmiewanych i potępianych przez Klemensa. Rozdział trzeci identyfikuje greckich bogów z demonami, podlegającymi namiętnościom. W rozdziale czwartym krytyka pogaństwa osiaga swój szczyt z długotrwałym atakiem skierowanym na kult posagów i obrazów bóstw pogańskich. Rozdział piąty opisuje poglądy greckich filozofów i potępia ubóstwianie przez nich elementów kosmosu. Ta problematyka jest kontynuowana w następnych partiach tekstu. Rozdział szósty rozpoczyna argumentatio, w którym religia chrześcijańska jest intuicyjnie poprzedzona prawdami, propagowanymi przez greckich filozofów, a szczególnie w nauczaniu Platona. W rozdziale siódmym są zawarte fragmenty poezji greckiej, które przepowiadają chrześcijańskiego Boga. Rozdział ósmy, po filozofach i poetach greckich, prezentuje biblijnych proroków głoszących głębsze poznanie prawdy o Bogu. Rozdział dziewiąty ukazuje wypracowaną teologię Logosu i opisuje posługując się różnymi obrazami miłość Boga do ludzi. Szczególnie rozwinięte jest pojęcie Boga jako prawdziwego Ojca

${ }^{53}$ Por. H. Chadwick, The Early Church, Baskerville 1993³, s. 94; S.G. Hall, Doctrine and Practice in the Early Church, Grand Rapids 1991, 96; Moreschini - Norelli, Storia della letteratura, s. 362: „In effetti, il «Protrettico» di Clemente presenta molti punti in commune con gli apologisti, e in modo tutto particolare con Atenagora, che è stato proposto talora di riconoscere nel suo primo maestro, quello della Grecia".

${ }^{54}$ Por. M. Simonetti, Letteratura cristiana antica. Dalle origini al terzo secolo, t. 1, Casale Monferrato 1996, 454: „Alcune sue opera - il «Protrettico», il «Pedagogo» - sono destinate a un publico più vasto e risentono della tradizione protrettica della filosofia greca".

${ }^{55}$ Por. S. van der Meeren, Le Protréptique en philosophe essaie de definition d'un genre, REG 115 (2002) 600-602; D. Dainese, Passibilità divina. La dottrina dell'anima in Clemente alessandrino, Roma 2002, 28-29. 
ludzkości. Rozdział dziesiąty, w porównaniu z poprzednimi jest najdłuższy, argumentatio zaś osiagga w nim swój szczyt. Apologeta z Aleksandrii wskazuje na grecką tradycję będącą przyczyną zniewolenia i demoralizacji. Proponuje on prawdziwą religię, która stoi w opozycji do ówczesnych zabobonów. Rozdział jedenasty opisuje korzyści, jakimi Boski Logos obdarowuje ludzi. Używając różnych metafor, a zwłaszcza metafory światła zapowiada przejście do peroratio. Rozdział dwunasty wieńczy peroratio z mocną zachętą do nawrócenia na chrześcijaństwo i uczestnictwa w misteriach Boskiego Logosu ${ }^{56}$.

Klemens, na początku Protreptyku, krytykuje Orfeusza, Amfiona oraz Ariona za doprowadzenie ludzi do upadku, ponieważ oni, poprzez swoją działalność artystyczną sprawili, że istoty ludzkie stały się zniewolonymi bałwochwalcami, oddającymi część materialnym posagom ${ }^{57}$. Następnie Aleksandryjczyk przedstawia boskiego Artystę, opisując Jego twórczość w perspektywie personalistycznej eikonantropologii:

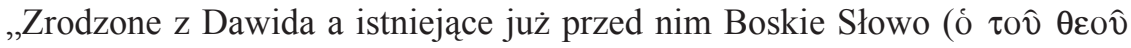

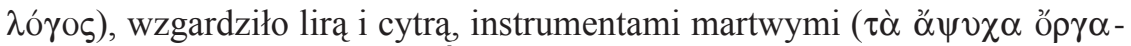
$v \alpha$ ). Pod tchnieniem Ducha Świętego ułożyło w harmonijny porządek za-

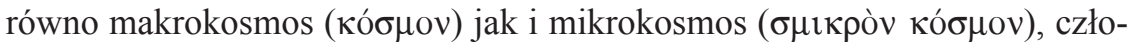

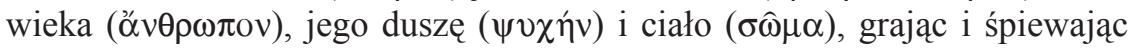

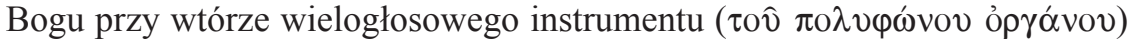

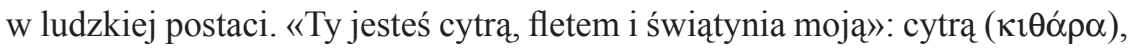
ze względu na harmonię ( $\alpha \rho \mu o v i ́ \alpha v)$, fletem ( $\alpha$ $\lambda$ ós), ze względu na tchnie-

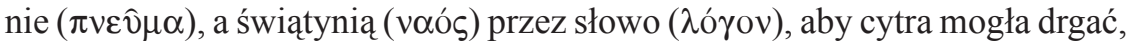
flet napełniał się powietrzem a świątynia obejmowała Pana (кúpıov)"s8.

Całe stworzenie, w opinii Apologety z Aleksandrii, jest dziełem Boskiego Logosu, który powołał do istnienia makrokosmos oraz człowieka, nazywając go

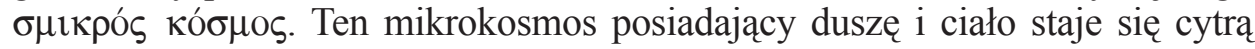

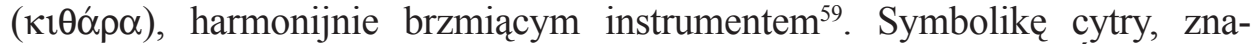
ną w kulturze helleńskiej, wykorzystują już Ojcowie Apostolscy. Św. Ignacy z Antiochii w Liście do Efezjan porównuje relacje między biskupem i kapłanami do zestrojenia strun $\mathrm{z}$ cytrą ${ }^{60}$. Apologeta $\mathrm{z}$ Aten, Atenagoras, prezentuje

${ }^{56}$ Por. Moreschini - Norelli, Storia della letteratura, s. 362-363.

${ }^{57}$ Por. Clemens Alexandrinus, Protrepticus I 3, 1, ed. C. Mondésert, SCh 2bis, Paris 20132, 55.

${ }^{58}$ Tamże I 5, 3, SCh 2bis, 55, tłum. J. Sołowianiuk: Klemens Aleksandryjski, Zachęta Greków, PSP 44, 118. Por. Daniélou, Messaggio evangelico, s. 296; B. Mondin, Storia della teologia, t. 1, Bologna 1996, 195.

${ }^{59}$ Por. Clemens Alexandrinus, Paedagogus II 44, 4, ed. C. Mondésert, SCh 108, Paris 1991,

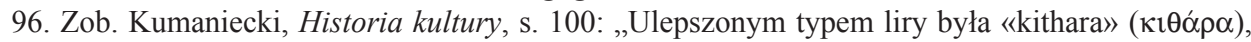
instrument sporządzony całkowicie z drzewa, większy od liry, zaopatrzony w większe pudło i dlate-

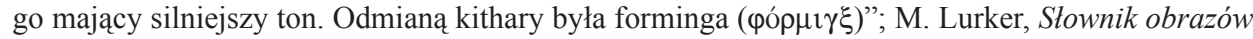
i symboli biblijnych, tłum. K. Romaniuk, Poznań 1989, 66.

${ }^{60}$ Por. Ignatius Antiochenus, Epistula ad Ephesios 4, 1, ed. K. Lake, LCL 24, Cambridge - 
starotestamentalnych proroków jako instrumenty Ducha Bożego, który gra na nich jak flecista na flecie ${ }^{61}$. Ciekawy opis cytry i harfy można znaleźć także w $\mathrm{Ho}$ miliach o Księdze Psalmów Orygenesa, przetłumaczonych przez św. Hieronima:

„Harfa jest to rodzaj instrumentu muzycznego, podobnego do cytry. Jest podobny do cytry, ale nie jest cytrą. Różnica między harfą i cytrą polega na tym, że w cytrę uderza się od dołu, a w harfę od góry i w języku popularnym nazywa się ona poliftongiem. Tak więc wygląda harfa" ${ }^{2}$.

Kontynuując rozważania o genezie osoby ludzkiej autor Protreptyku podkreśla, że jej Stwórcą jest Boski Logos:

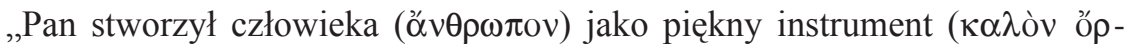

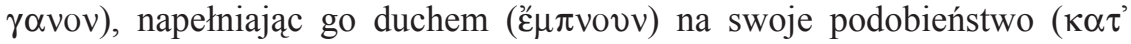

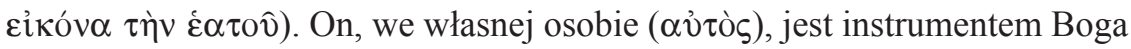

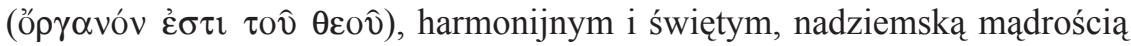
i boskim Logosem (oủpóvios $\lambda$ óros)" ${ }^{63}$.

Istota rozumna, powołana do istnienia przez Logos, jest nie tylko mikrokosmosem, podobnym przez akt stwórczy do makrokosmosu, lecz także uczy-

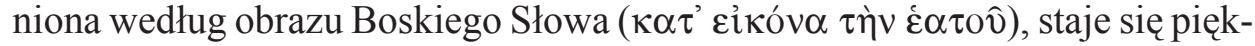
nym instrumentem ( $\kappa \alpha \lambda$ òv óp $\gamma \alpha v o v)$. W tym pięknym instrumencie - osobie

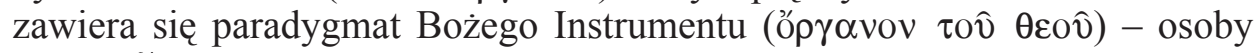
$\operatorname{Logosu}^{64}$. Metafora instrumentu muzycznego wskazuje na sferę analogiczno-ikoniczną, w której powstaje interpersonalna relacja między niestworzonym i stworzonym instrumentem muzycznym, Logosem i Jego pięknym obrazem. Józef Tischner, krakowski filozof, zafascynowany metaforą instrumentu muzycznego, użytą także przez św. Grzegorza z Nyssy, pisze: „Człowiek jest jak płynąca przez czas - pieśń. Kto gra ową pieśń? Sam człowiek jest tu instrumentem i artystą. Według jakich wartości człowiek wygrywa własne życie? Niełatwo na to odpowiedzieć. Często wydaje się, że jest tyle wartości i tyle

London 1985, 222, tłum. A. Świderkówna, w: Pierwsi świadkowie. Pisma Ojców Apostolskich, BOK 10, Kraków 2010², 114: „Wasi bowiem kapłani, słusznie szanowani i godni Boga, tak są zestrojeni z biskupem jak struny z cytrą".

${ }^{61}$ Por. Athenagoras, Legatio pro Christianis 7 i 9, ed. W.R. Schoedel, Oxford Early Christian Texts 38, Oxford 1972, 156, tłum. S. Kalinkowski, w: Atenagoras z Aten, Prośba za chrześcijanami. O zmartwychwstaniu umartych, Warszawa 1985, 36 i 38: „Również wy, którzy przewyższanie innych ludzi inteligencją i pobożnością, względem prawdziwego Bóstwa możecie stwierdzić, że niedorzecznością jest odrzucać wiarę w Ducha Bożego, który usta proroków poruszał niczym instrumenty muzyczne [...] bo Duch posługiwał się nimi jak flecista, który dmie w flet".

${ }^{62}$ Origenes - Hieronymus, Tractatus sive homiliae in psalmos I 59, 3, ed. G. Morin, CCL 78, Turnhout 1958, 395, thum. S. Kalinkowski: Orygenes - Hieronim, Homilie o Księdze Psalmów, ŹMT 32, Kraków 2004, 340.

${ }^{63}$ Clemens Alexandrinus, Protrepticus I 5, 4, SCh 2bis, 58, PSP 44, 120 [ze zmianami w thumaczeniu - A.K.]. Por. Daniélou, Messaggio evangelico, s. 227.

${ }^{64}$ Por. Clemens Alexandrinus, Protrepticus I 6, 2, SCh 2bis, 59. 
«ludzkich partytur», ilu ludzi na świecie" ${ }^{65}$. Kontynuując swoje rozważania na temat interpersonalnych relacji Logosu i Jego obrazu Aleksandryjczyk konstatuje:

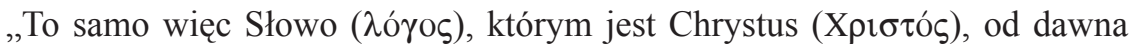

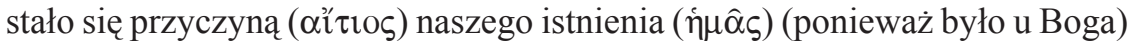
i naszego dobra ( $\varepsilon \hat{\text { ) }) ~(p o n i e w a z ̇ ~ p o j a w i ł o ~ s i e ̨ ~ w s ́ r o ́ d ~ l u d z i) . ~ T o ~ s a m o ~ S ł o w o, ~}$

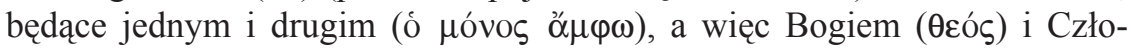
wiekiem (óv $v \rho \omega \pi \circ \varsigma)$, ukazało się ludziom jako przyczyna wszystkich dóbr

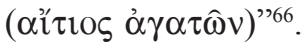

Klemens z Aleksandrii, podobnie jak św. Justyn, identyfikuje Logos z Chrystusem, będącym przyczyną ( $\alpha^{\prime \prime} \tau$ ios) osoby ludzkiej zaistniałej w porządku ontologicznym oraz na płaszczyźnie egzystencjalnej, mającej swój wyraz w ekonomii Boga. Aleksandryjczyk wyraźnie stwierdza, że Logos, inaczej niż pisze Filon, jest jednocześnie Istotą boską i ludzka. Filozof chrześcijański, posługując się zwrotem ó $\mu$ óvos ő $\mu \varphi \omega$, wyraża prawdę o dwóch naturach

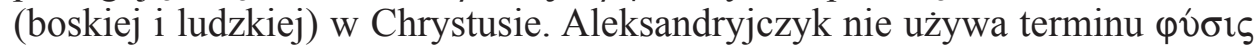
(natura), jednak definiuje podstawową regula fidei chrześcijaństwa, zatwierdzoną uroczyście, po przeszło dwustu pięćdziesięciu latach, przez Ojców Soboru Chalcedońskiego ${ }^{67}$.

Aleksandryjczyk w swojej personalistycznej eikonantropologii, prezentując naukę o stworzeniu człowieka zauważa, że istoty ludzkie przed pojawieniem się na świecie jako mikrokosmosy oraz piękne instrumenty Logosu, już wcześniej zaistniały w stwórczych planach Boga:

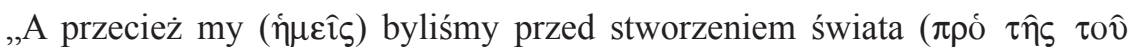

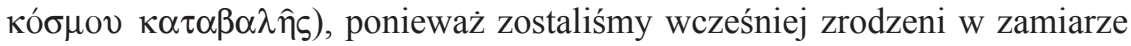

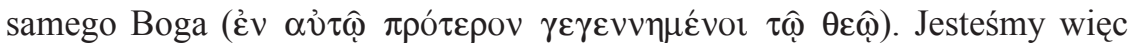

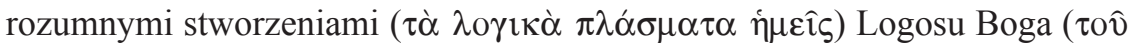
$\theta \varepsilon \circ \hat{v} \lambda$ ó $\gamma 0 v)$, bo «na początku był Logos». Skoro na początku był Logos. On

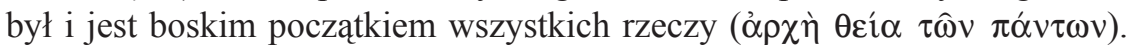

${ }^{65}$ J. Tischner, Etyka wartości i nadziei, w: tenże, Wobec wartości, Poznań 1984, 57. Por. A. Kowalski, Inspiracje patrystyczne w dziełach J. Tischnera, w: Józef Tischner: prawda, wolność, dialog, red. D. Jacyk - M. Manikowski, Wrocław 2013, 29-30: „Człowiek - artysta wydobywa dźwięki, posługując się swoim psychofizycznym instrumentem. Mogą być one harmonią lub kakofonią w relacji do partytury aksjologicznej dobra lub zła. Wirtuoz ludzki, odczytując świat wartości, zawarty w ustnym lub pisemnym przekazie aksjologicznym, odtwarza lub tworzy, na miarę swoich możliwości, własną pieśń aksjologiczną wyśpiewaną dla drugiego człowieka".

${ }^{66}$ Clemens Alexandrinus, Protrepticus I 7, 1, SCh 2bis, 60, PSP 44, 121.

${ }^{67}$ Por. Concilium Chalcedonense, Definitio fidei 11, ŹMT 33 [tekst grecko-polski, układ i oprac. A. Baron - H. Pietras], Kraków 2005 = DSP 1, 222-223; S.W. Need, Truly Divine and Truly Human. The Story of Christ and the Seven Ecumenical Councils, London 2008, 101. 
Przybrał dawne, święte imię, zasługujące na najwyższą cześć, imię Chrystusa,

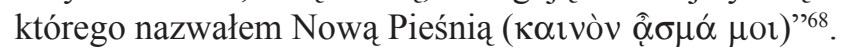

Klemens z Aleksandrii, podobnie jak Filon, prezentuje doktrynę o podwójnym stworzeniu człowieka ${ }^{69}$. Aleksandryjczyk nie wymienia $\mathrm{w}$ prezentowanym tekście ludzkiego rodzaju i gatunku - mężczyzny i niewiasty, ale stosuje zaimek osobowy w liczbie mnogiej ì $\mu \varepsilon \hat{\imath} \varsigma$ (my). Można powiedzieć, że to greckie słowo $\eta \mu \varepsilon \hat{\iota} \varsigma$ zawiera w sobie tak zwanych ludzi niebiańskich zrodzonych ( $\gamma \varepsilon \gamma \varepsilon v \nu \eta \mu \varepsilon ́ v 0 r)$, a niestworzonych przez Boga. W filozofii greckiej nie istnieje koncepcja creatio ex nihilo. Kreacjonizm, będący w opozycji do poglądów dualistycznych i emanacyjnych, pojawia się jako koncepcja filozoficzna za sprawą religii chrześcijańskiej ${ }^{70}$. Apologeta z Aleksandrii nawiązuje do poglądów Heraklita z Efezu, który naucza, że świat, podobnie i człowiek, rodzi się w myślowej strukturze pozaczasowej ${ }^{71}$. Antropogeneza noetyczna w myśli Boga wyprzedza Jego kosmogenezę, realizującą się jako akt stwórczy objawiającego się Absolutu ${ }^{72}$. A zatem ludzie pojawiają się w Boskim Logosie

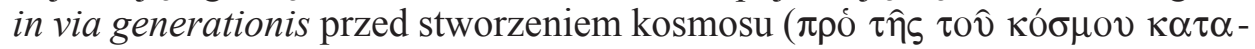
$\left.\beta \alpha \lambda \eta_{\varsigma}\right)$. Należy podkreślić, że według Klemensa z Aleksandrii, istoty ludzkie

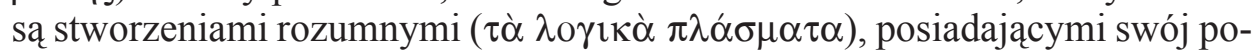
czątek i jednocześnie obdarzonymi rozumnością. Autor Protreptyku, cytując dosłownie początek prologu Ewangelii według św. Jana (J 1, 1), stwierdza, że

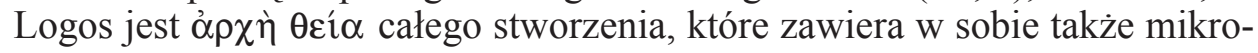
kosmos. Orygenes, w Komentarzu do Ewangelii wedtug św. Jana interesująco

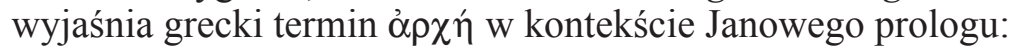

„Nadto «początek» definiujemy jako «wzór» w zakresie formy; tak więc, jeśli Pierworodny wszelkiego stworzenia jest obrazem niewidzialnego Boga, to Jego «początkiem» jest Ojciec. Tak samo i Chrystus jest «początkiem» istot stworzonych na obraz Boży. Jeśli bowiem ludzie istnieją «według» obrazu, a obraz «wedle Ojca», zatem wzorem dla Chrystusa jest Ojciec, który stanowi początek, natomiast wzorem w odniesieniu do ludzi jest Chrystus, bo ludzie zostali stworzeni nie wedle tego, czego obrazem jest Chrystus, ale według

\footnotetext{
${ }^{68}$ Clemens Alexandrinus, Protrepticus I 6, 4-5, SCh 2bis, 59-60, PSP 44, 121.

${ }^{69}$ Por. Daniélou, Messaggio evengelico, s. 227-228; J. Rizzerio, Creazione e antropologia di Clemente di Alessandria, w: Dizionario di Spiritualità Biblico-Patristica, t. 11: Creazione - Uomo - Donna, Città di Castello 1995, 121-122; N. Osmański, Logos i stworzenie. Filozoficzna interpretacja traktatu „De opificio mundi” Filona z Aleksandrii, Lublin 2001, 107-129.

${ }^{70}$ Por. W. Tatarkiewicz, Dzieje sześciu pojęć. Sztuka - piękno - forma-twórczość - odtwórczość - przeżycie estetyczne, Warszawa 1988, 300.

${ }^{71}$ Por. tamże, s. 222.

${ }^{72}$ Por. tamże, s. 91: „Czasownik «stwarzać» odnosi się do objawienia czegoś, a nie do stwarzania jakiejś rzeczywistości «z niczego»”.
} 
samego obrazu. Z przykładem tym harmonizuje zdanie: «Na początku było Słowo» $(\mathrm{J} 1,1)^{\text {"’73 }}$.

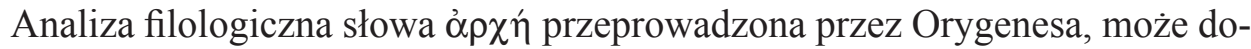
pomóc w interpretacji następującego tekstu Klemensa:

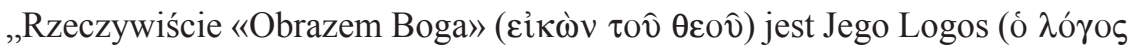

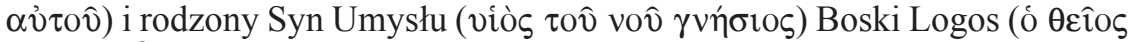

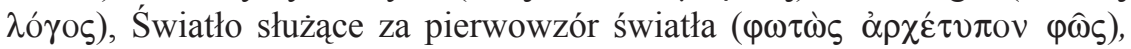

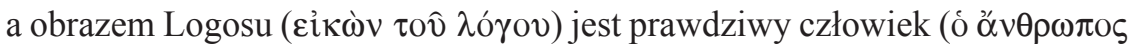

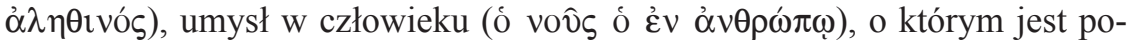
wiedziane, że został stworzony «na obraz i podobieństwo Boże» $(\operatorname{Rdz} 1,26)$

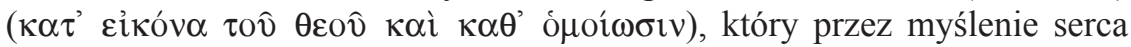

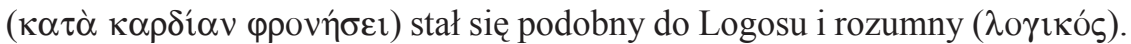
Ziemskim odbiciem widzialnego i ziemskiego człowieka są posagi uczynione

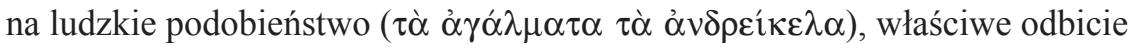

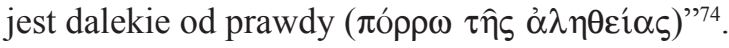

Aleksandryjczyk wyjaśniając koncepcję obrazu-paradygmatu nawiązuje do doktryny Filona z Aleksandrii, który pisze o Logosie jako ikonie Boga, zaś rozum ludzki nazywa boskim darem ${ }^{75}$. Klemens, w swojej personalistycznej eikonantropologii identyfikując Chrystusa z Logosem proponuje następujący schemat:

\section{Bóg ( $\theta \varepsilon o ́ \varsigma)$}

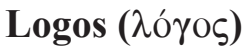

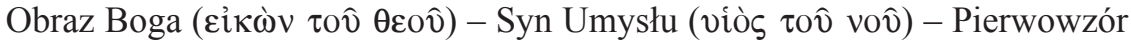

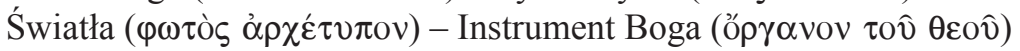

\section{Czlowiek (óv $\theta \rho \omega \pi \mathrm{s})$}

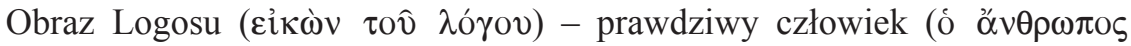

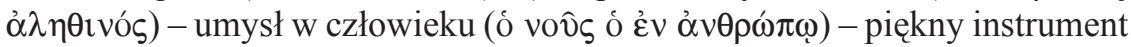

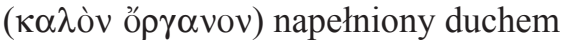

Podobny opis Logosu oraz człowieka stworzonego na Jego obraz Apologeta Aleksandryjski zamieszcza w swoim późniejszym traktacie zatytułowanym Stromata: „Obrazem mianowicie Boga jest Słowo Boże i królewskie, Człowiek pozbawiony afektu. Odbiciem zaś obrazu - ludzki rozum"76. Osoba

${ }^{73}$ Origenes, In Joannem comm. I 17, 104-105, ed. C. Blanc, SCh 120, Paris 1966, 115-117, thum. S. Kalinkowski: Orygenes, Komentarz do Ewangelii wedlug św. Jana, ŹMT 27, Kraków 2005, 47.

${ }^{74}$ Clemens Alexandrinus, Protrepticus X 98, 4, SCh 2bis, 166-167, PSP 44, 187. Por. Grossi, Lineamenti di antropologia patristica, s. 48.

${ }^{75}$ Por. Osmański, Logos i stworzenie, s. 107-129.

${ }^{76}$ Clemens Alexandrinus, Stromata V 94, ed. O. Stählin - L. Frühtel, GSC 52, Berlin 1960, 382, tłum. J. Niemirska-Pliszczyńska: Klemens Aleksandryjski, Kobierce zapisków filozoficznych dotyczacych prawdziwej wiedzy, t. 2, Warszawa 1994, 74-75. Por. Daniélou, Messaggio evangelico, 


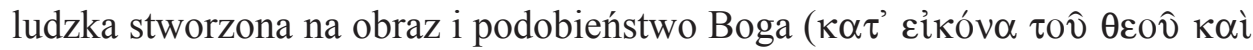
$\kappa \alpha \theta^{\prime}$ ó $\mu o^{\prime}(\omega \sigma \imath v)$ staje się ikoną Logosu przez myślenie sercem. Proces ten należy do porządku noetycznego. Autor Protreptyku nie wyjaśnia jednak, na

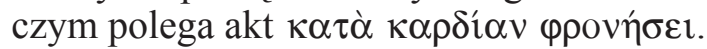

Klemens wypowiada się również na temat posagów uczynionych na obraz ludzki ( $\tau \grave{\alpha} \dot{\alpha} \gamma \alpha \dot{\alpha} \lambda \mu \alpha \tau \alpha \tau \grave{\alpha} \dot{\alpha} \nu \delta \rho \varepsilon i ́ \kappa \varepsilon \lambda \alpha$ ), które nie odzwierciedlają prawdziwego podobieństwa do człowieka. W starożytności posagi bogów były często utożsamiane z bóstwem. Aleksandryjczyk, podobnie jak Celsus z Aleksandrii $^{77}$, powołując się na autorytet Heraklita z Efezu zauważa:

„Jeśli jednak nie chcesz słuchać prorokini [Sybilli], to przynajmniej posłuchaj,

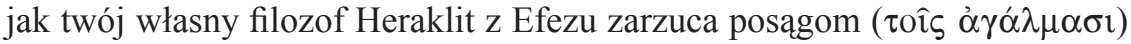

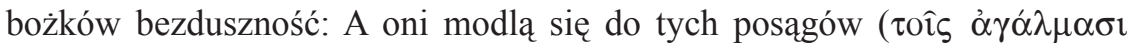

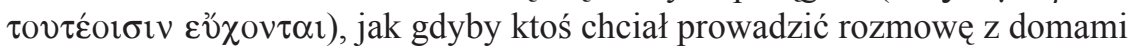

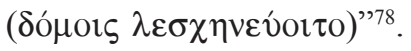

Apologeta chrześcijański nie akceptuje religijności pogańskiej ukazując jej bezduszność. Kult posąów, tak rozpowszechniony w politeizmie, wskazuje na bezbożność, przejawiającą się między innymi w akcie modlitwy skierowanej do rzeczy (posag porównany z domem), a nie do osoby bóstwa. Aleksandryjczyk umiejętnie wykorzystuje w swojej personalistycznej eikonantro-

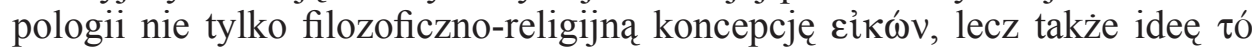
ó $\gamma \alpha \lambda \mu \alpha$ praktykowaną w obrzędowości misteriów. Klemensowa dezaprobata wobec kultu posagów oraz krytyka ich twórców stanowi punkt wyjścia do sformułowania intrygującej tezy o Bogu, będącym Duchowym Posąiem:

„Natomiast posagi ( $\tau \dot{\alpha} \alpha \dot{\alpha} \gamma \alpha \dot{\lambda} \mu \alpha \tau \alpha)$ bożków są bezczynne ( $\alpha \gamma \rho \alpha ́)$, nieużyteczne i bezduszne, są przywiązane, przybite, przymocowane, odlewane [z metalu], piłowane, polerowane, ociosywane i rzeźbione. W rzeczywistości wykonawcy posagów (oi $\alpha \gamma \alpha \lambda \mu \alpha \tau o \pi$ otoí) «znieważają nieczuła ziemię»,

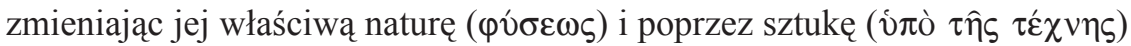

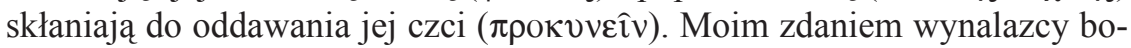
gów ( $\theta \varepsilon 0 \pi 010 i ́)$ nie czczą bogów ( $\theta \varepsilon o v ́ \varsigma)$ lub demonów ( $\delta \alpha i ́ \mu o v \alpha \varsigma$ ), lecz zie-

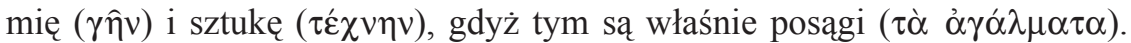

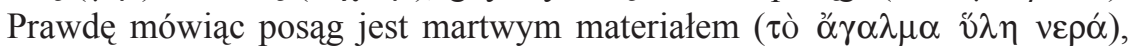

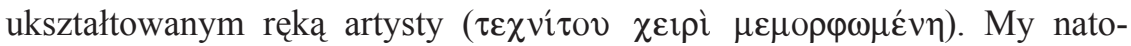
miast nie mamy posagu dostrzegalnego zmysłami i uczynionego $\mathrm{z}$ widzial-

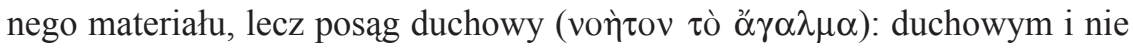

s. 115; J.M. Szymusiak, Klemens Aleksandryjski (ok. 150-211), w: Drogi zbawienia. Od Biblii do Soboru, red. B. Przybylski, Poznań 1970, 308; Nellas, Voi siete dèi, s. 37-55.

${ }^{77}$ Por. Celsus, Contra Christianos 1, 5a, ed. S. Rizzo, Milano 1994, 62-64. Zob. M. Ożóg, Kościót starożytny wobec światyń oraz posagów bóstw, Kraków 2009, 52-53.

${ }^{78}$ Clemens Alexandrinus, Protrepticus IV 50, 4, SCh 2bis, 112, PSP 44, 153-154. 
postrzegalnym zmysłami [posagiem] jest Bóg ( $\theta \varepsilon o ́ \varsigma)$, jeden rzeczywiście istniejący Bóg"79.

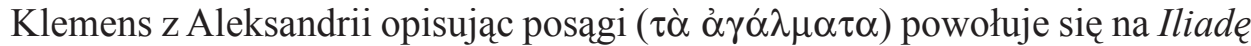
Homera, który stwierdza, że ziemia nie posiada uczuć, dlatego też jest nieczu$\mathfrak{1 a}^{80}$. Apologeta chrześcijański zarzuca wykonawcom posagów ( $\dot{\alpha} \gamma \alpha \lambda \mu \alpha \tau$ $\pi$ oıó́), że są wynalazcami bogów ( $\theta \varepsilon \circ \pi$ otoí). Zmieniając naturę ziemi przypisują jej charakter sakralny, przejawiający się w kulcie pogańskich bożków. W opinii autora Proptreptyku posagi są przede wszystkim martwym materiałem, dziełem sztuki, uczynionym ręką ludzkiego artysty. Bóg jest największym Artysta, którego dzieła są o wiele bardziej doskonałe, niż najpiękniejsze arcydzieło ludzkich rąk. Klemens z Aleksandrii, podobnie jak Atenagoras z Aten, wskazuje na istotną różnicę między wiecznym Bogiem, dostrzegalnym tylko dla umysłu, a stworzoną materią postrzegalną zmysłami ${ }^{81}$.

Koncepcja Boga jako Duchowego Posagu (voì teresującą próbą przedstawienia monoteizmu chrześcijańskiego, skierowaną do społeczności politeistycznej. Aleksandryjczyk wykorzystuje kult posagów, a zarazem per analogiam thumaczy naukę chrześcijan, którzy wierzą w jedynego i niewidzialnego Boga. Orygenes w traktacie De principiis posługuje się metaforą posagu wyjaśniając tajemnicę Trójcy Świętej, a szczególnie zachodzącą relację między Bogiem Ojcem i Synem Bożym:

„Załóżmy więc, że istnieje jakiś posagg, który ogromem swoim obejmuje cały świat i z powodu tej jego wielkości nikt go nie może obejrzeć; przypuśćmy dalej, że istnieje i drugi posag podobny do tamtego pod każdym względem w wyglądzie zewnętrznym, rysach twarzy, kształcie i materiale, z którego został wykonany - z jednym wyjątkiem wielkości: ludzie więc, którzy nie mogą dostrzec i obejrzeć wielkiego posagu, ujrzawszy mały posag mogliby sądzić, że widzieli i tamten - a to z powodu ich ścisłego wzajemnego podobieństwa w wyglądzie zewnętrznym, rysach twarzy, kształcie"s2.

Osoba ludzka, według personalistycznej eikonantropologii Klemensa, jest również widzialną, poruszającą się statuą, w której przebywa Obraz Duchowego Posagu (Boga):

„My - właśnie my - jesteśmy tymi, którzy w żyjącym i poruszającym się

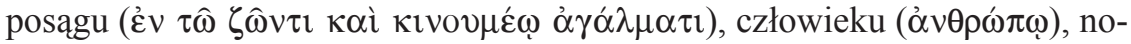

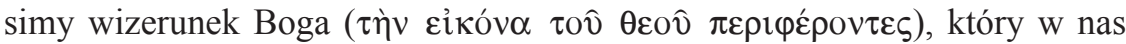

${ }^{79}$ Tamże IV 51, 5-6, SCh 2bis, 113-114, PSP 44, 154-155.

${ }^{80}$ Por. Homerus, Ilias 24, 54.

${ }^{81}$ Por. Athenagoras, Legatio pro Christianis 4.

${ }^{82}$ Origenes, De principiis I 2, 8, ed. H. Crouzel - M. Simonetti, SCh 252, Paris 1978, 126-128, thum. S. Kalinkowski: Orygenes, O zasadach, ŹMT 1, Kraków 1996, 73. Por. M. Manikowski, Filozofia w obronie dogmatu. Argumenty antytryteistyczne Grzegorza z Nyssy na tle Tradycji, Wrocław 2002, 102-105. 
mieszka ( $\sigma u ́ v o \imath \kappa o v)$, jest naszym doradcą, towarzyszem, współbojownikiem, który dzieli nasze uczucia" ${ }^{" 3}$.

W koncepcji człowieka jako żywego i poruszającego się posagu Apologeta z Aleksandrii nawiązuje do Księgi Rodzaju (Rdz 2, 7). Istota rozumna będąc stworzonym przez Boga posagiem, zawiera w sobie obraz Logosu, który przebywa w mikrokosmosie. Osoba ludzka jest także pięknym instrumentem ( $\alpha \lambda \lambda$ òv ö $\rho \gamma \alpha v o v)$ - cytrą, napełnionym duchem i uczynioną ikoną Logosu. Personalistyczna eikonantropologia naszego autora wskazuje na sferę analogiczno-ikoniczną, która opisuje człowieka jako widzialny posag-obraz zamieszkały przez niewidzialną osobę Logosu. Ten Boski Logos będąc towarzyszem, doradcą i współbojownikiem człowieka tworzy interpersonalne relacje bosko-ludzkie.

Klemens z Aleksandrii prezentując personalistyczną eikonantropologię ukazuje jej bezpośrednie odniesienia do teologii, chrystologii i antropologii. Protologia i eschatologia Aleksandryjczyka wyjaśniając ekonomię Bożą, w relacji do osoby ludzkiej, wskazują na szczególną i uprzywilejowaną rolę żywej ikony Logosu - posagu zamieszkałego przez Syna Bożego w historii zbawienia:

$$
\begin{gathered}
\text { Bóg - Duchowy Posąg } \\
\text { Logos - Obraz Boga - Obraz Duchowego Posagu }
\end{gathered}
$$

Człowiek - żywa ikona Logosu - posąg zamieszkały przez Boski Logos

$$
* * *
$$

Personalistyczne ujęcie człowieka zawarte w Protreptyku, prezentuje nie tylko zależność Aleksandryjczyka od wcześniejszych antropologii Filona z Aleksandrii, Atenagorasa z Aten, personalistycznej logos-antropologii św. Justyna, czy też personalistycznej somatoantropologii św. Ireneusza, lecz także podkreśla oryginalność jego personalistycznej eikonantropologii. Personalizm Apologety z Aleksandrii demonstruje protologię i eschatologię, które uczą, w jaki sposób stworzona osoba ludzka może stać się Bogiem:

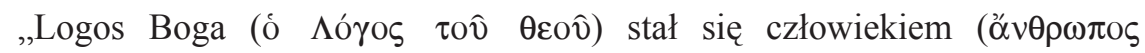
$\gamma \varepsilon v o ́ \mu \varepsilon v o \zeta)$, abyś ty także nauczył się od człowieka, w jaki sposób będąc

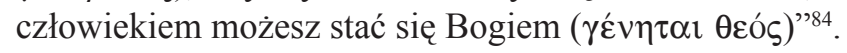

Personalistyczna eikonantropologia Klemensa z Aleksandrii, zawarta także w jego Pedagogu oraz Stromatach ${ }^{85}$, będzie kontynuowana w traktatach

\footnotetext{
${ }^{83}$ Clemens Alexandrinus, Protrepticus IV 59, 2, SCh 2bis, 123, PSP 44, 161.

${ }^{84}$ Tamże I 8, 4, SCh 2bis, 63, PSP 44, 123: „Słowo stało się człowiekiem, abyś ty także nauczył się od człowieka, w jaki sposób będąc człowiekiem możesz stać się Bogiem".

${ }^{85}$ Por. A. Kowalski, Personalizm w , Stromatach” Klemensa Aleksandryjskiego, w: Personalizmus a súčastnost', I, red. P. Dancák - D. Hruška - M. Rembierz - R. Šoltés, Prešov 2010, 188-192.
} 
Orygenesa, Ojców Kapadockich oraz innych greckich i łacińskich pisarzy wczesnochrześcijańskich. Autorzy Katechizmu Kościoła Katolickiego, opracowanego po Vaticanum II, potwierdzają tezy personalizmu patrystycznego, według których istota ludzka jest osobą - imago Dei:

„Człowiek, ponieważ został stworzony na obraz Boży, posiada godność osoby: nie jest tylko czymś, ale kimś. Jest zdolny poznawać siebie, panować nad soba, w sposób dobrowolny dawać siebie oraz tworzyć wspólnotę z innymi osobami; przez łaskę jest powołany do przymierza ze swoim Stwórcą do dania Mu odpowiedzi wiary i miłości, jakiej nikt inny nie może za niego dać"»6.

\section{QUESTION OF PERSONALISM IN PROTREPTICUS OF CLEMENT OF ALEXANDRIA}

\section{(Summary)}

The article presents the outline of the pagan and Christian ancient anthropology that is interested in its relations to the cosmology. The antique philosophers describe a man as the microcosmos which belongs to the macrocosmos. According to Aristotle's metaphysics and the henological metaphysics, the human being occupies the lower place in the hierarchy of the universe. The Christian thinkers, based on the Bible and the Tradition, show the human being as God's creature made according to the image and similitude of his Creator. The Church Fathers know the Jewish and gnostic anthropologies and they make a polemic on their doctrinal issues. Investigating the patristic anthropology is possible to apply the prosopography exegesis that underlines the interpersonal dialogue. That method indicates three levels of mutual relationships: the analogical and iconic one, the dyadic and dialogical level and the triadic one. The Church Fathers creating the metaphysics of person change their research from the cosmology to the theology and the anthropology. Justin investigates the personalist logos-anthropology. Irenaeus of Lyon and Tertullian of Carthage show the personalist soma-anthropology. Clement of Alexandria elaborates the very interesting concept of the personalist eikon-anthropology that describes the human person as the divine Logos' image, the living statue, in which dwells the divine Logos and the beautiful instrument fulfilled by God with the spirit. Origen of Alexandria, the Cappadocian Fathers and other Christian thinkers who examine that issue, will use Clément's personalist eikon-anthropology in their future investigations. That concept helps to define the solemn Christological doctrine of Council of Chalcedon.

Key words: anthropology, cosmology, theology, metaphysics, prosopography exegesis, person, logos, image, Church Fathers, Bible, Tradition.

\footnotetext{
${ }^{86} \mathrm{KKK} 357$.
} 
Slowa kluczowe: antropologia, kosmologia, teologia, metafizyka, egzegeza prosopograficzna, osoba, logos, obraz, Ojcowie Kościoła, Biblia, Tradycja.

\section{BIBLIOGRAFIA}

\section{Źródła}

Aristoteles, Ethica nicomachea, ed. O. Apelt, Leipzig 1912, tłum. D. Gromska: Arystoteles, Etyka nikomachejska, Warszawa 1982.

Athenagoras, Legatio pro Christianis, ed. W.R. Schoedel, Oxford Early Christian Texts 38, Oxford 1972, tłum. S. Kalinkowski, w: Atenagoras z Aten, Prośba za chrześcijanami. O zmartwychwstaniu umartych, Warszawa 1985, 27-80.

Benedictus XVI, Catechesis patristica, OsRom 147 (2007) nr 88, s. 4, thum. pol.: Benedykt XVI, Katechezy o Ojcach Kościoła, Kraków 2008.

Celsus, Contra Christianos, ed. S. Rizzo, Milano 1994.

Clemens Alexandrinus, Paedagogus, ed. C. Mondésert, SCh 108, Paris 1991.

Clemens Alexandrinus, Protrepticus, ed. C. Mondésert, SCh 2bis, Paris 2013, thum. J. Sołowianiuk: Klemens Aleksandryjski, Zachęta Greków, PSP 44, Warszawa 1988, 116-201.

Clemens Alexandrinus, Stromata, ed. O. Stählin - L. Frühtel, GCS 52, Berlin 1960, tłum. J. Niemirska-Pliszczyńska: Klemens Aleksandryjski, Kobierce zapisków filozoficznych dotyczacych prawdziwej wiedzy, t. 1-2, Warszawa 1994.

Concilium Chalcedonense, Definitio fidei, w: ŹMT 33 [tekst grecko-polski, układ i oprac. A. Baron - H. Pietras], Kraków 2005 = DSP 1, 215-225.

Origenes - Hieronymus, Tractatus sive homiliae in psalmos, ed. G. Morin, CCL 78, Turnhout 1958, tłum. S. Kalinkowski: Orygenes - Hieronim, Homilie o Księdze Psalmów, ŹMT 32, Kraków 2004.

Origenes, De principiis, ed. H. Crouzel - M. Simonetti, I-II, SCh 252-253, Paris 1978; III-IV, SCh 268-269, Paris 1980; tłum. S. Kalinkowski: Orygenes, O zasadach, ŹMT 1, Kraków 1996.

\section{Opracowania}

A Patristic Greek Lexicon, ed. G.W.H. Lampe, Oxford $1989^{9}$.

CHadwick H., The Early Church, Baskerville 1993².

Copleston F., Historia filozofii, t. 1: Grecja i Rzym, tłum. H. Bednarek, Warszawa 1998.

Dainese D., Passibilità divina. La dottrina dell'anima in Clemente alessandrino, Roma 2002.

Daniélou J., Messaggio evangelico e cultura ellenistica, tłum. C. Prandi, Bologna 1975.

Dizionario illustrato greco-italiano, ed. H.G. Liddell - R. Scott - G. Cataudella, Firenze 1993.

Grossi V., Lineamenti di antropologia patristica, Città di Castello 1983.

Hall S.G., Doctrine and Practice in the Early Church, Grand Rapids 1991.

JAEGER W., Wczesne chrześcijaństwo i grecka paideia, tłum. K. Bielawski, Bydgoszcz 2002.

Kowalski A., Inspiracje patrystyczne w dziełach J. Tischnera, w: Józef Tischner: prawda, wolność, dialog, red. D. Jacyk - M. Manikowski, Wrocław 2013, 15-41. 
Kowalski A., Personalizm w ,,Stromatach” Klemensa Aleksandryjskiego, w: Personalizmus a súčastnost', I, ed. P. Dancák - D. Hruška - M. Rembierz - R. Šoltés, Prešov 2010, 183-194.

Kumaniecki K., Historia kultury starożytnej Grecji i Rzymu, Warszawa 1987.

Lebreton G. - Zeiller G., Storia della Chiesa, t. 1: La Chiesa primitive, Torino 1979.

LeŚnIAK K., Arystoteles, Warszawa 1989.

Lurker M., Słownik obrazów i symboli biblijnych, tłum. K. Romaniuk, Poznań 1989.

Manikowski M., Filozofia w obronie dogmatu. Argumenty antytryteistyczne Grzegorza z Nyssy na tle Tradycji, Wrocław 2002.

Mazzanti A.M., L'aggettivo $\mu$ fópios e la doppia creazione dell'uomo in Filone di Alessandria, w: La «doppia creazione» dell'uomo negli Alessandrini, nei Cappadoci e nella gnosi, ed. U. Bianchi, Roma 1978, 25-42.

MeERen van der S., Le Protréptique en philosophe essaie de definition d'un genre, REG 115 (2002) 591-621.

Mondin B., Storia della Teologia, t. 1, Bologna 1996.

Moreschini C.- Norelli E., Storia della letteratura cristiana antica greca e latina, t. 1: Da Paolo all'età costantiniana, Brescia 1995.

Need S.W., Truly Divine and Truly Human. The Story of Christ and the Seven Ecumenical Councils, London 2008.

Osmański M., Logos i stworzenie. Filozoficzna interpretacja traktatu „,De opificio mundi” Filona z Aleksandrii, Lublin 2001.

OżóG M., Kościół starożytny wobec światyń oraz posagów bóstw, Kraków 2009.

Reale G., Karol Wojtyła Pielgrzym absolutu, tłum. M. Gajda, Warszawa 2008.

ReALE G., Myśl starożytna, tłum. E.I. Zieliński, Lublin $2010^{2}$.

Rizzerio J., Creazione e antropologia di Clemente di Alessandria, w: Dizionario di Spiritualità Biblico-Patristica, t. 11: Creazione - Uomo - Donna, Città di Castello 1995, 105-129.

Simonetti M., Cristianesimo antico e cultura greca. Città di Castello 1990.

Simonetti M., La letteratura cristiana antica greca e latina, Milano 1988.

Simonetti M., Letteratura cristiana antica, t. 1: Dalle origini al terzo secolo, Casale Monferrato 1996.

Sinko T., Zarys literatury greckiej, t. 2, Warszawa 1959.

SoŁowianiuk J., Wstęp, w: Apologie, PSP 44, Warszawa 1988, 99-106.

Szymusiak J.M., Klemens Aleksandryjski (ok. 150-211), w: Drogi zbawienia. Od Biblii do Soboru, red. B. Przybylski, Poznań 1970, 307-309.

Tatarkiewicz W., Dzieje sześciu pojęć. Sztuka-piękno-forma-twórczość - odtwórczość - przeżycie estetyczne, Warszawa 1988.

Tischner J., Etyka wartości i nadziei, w: Wobec wartości, red. D. von Hildebrand J.A. Kłoczowski - J. Paściak - J. Tischner, Poznań 1984, 51-148. 
